PREPARED FOR THE U.S. DEPARTMENT OF ENERGY, UNDER CONTRACT DE-AC02-76CH03073

PPPL-3579

PPPL-3579

UC-70

\title{
Screening of Hydrocarbon Sources in JET
}

J.D. Strachan, W. Fundamenski, M. Charlet, K. Erents, J. Gafert, C. Giroud, M von Hellermann, G. Matthews, G. McCracken, V. Philipps,

J. Spence, M.F. Stamp, K-D. Zastrow, and EFDA-JET Work Programme Collaborators

June 2001
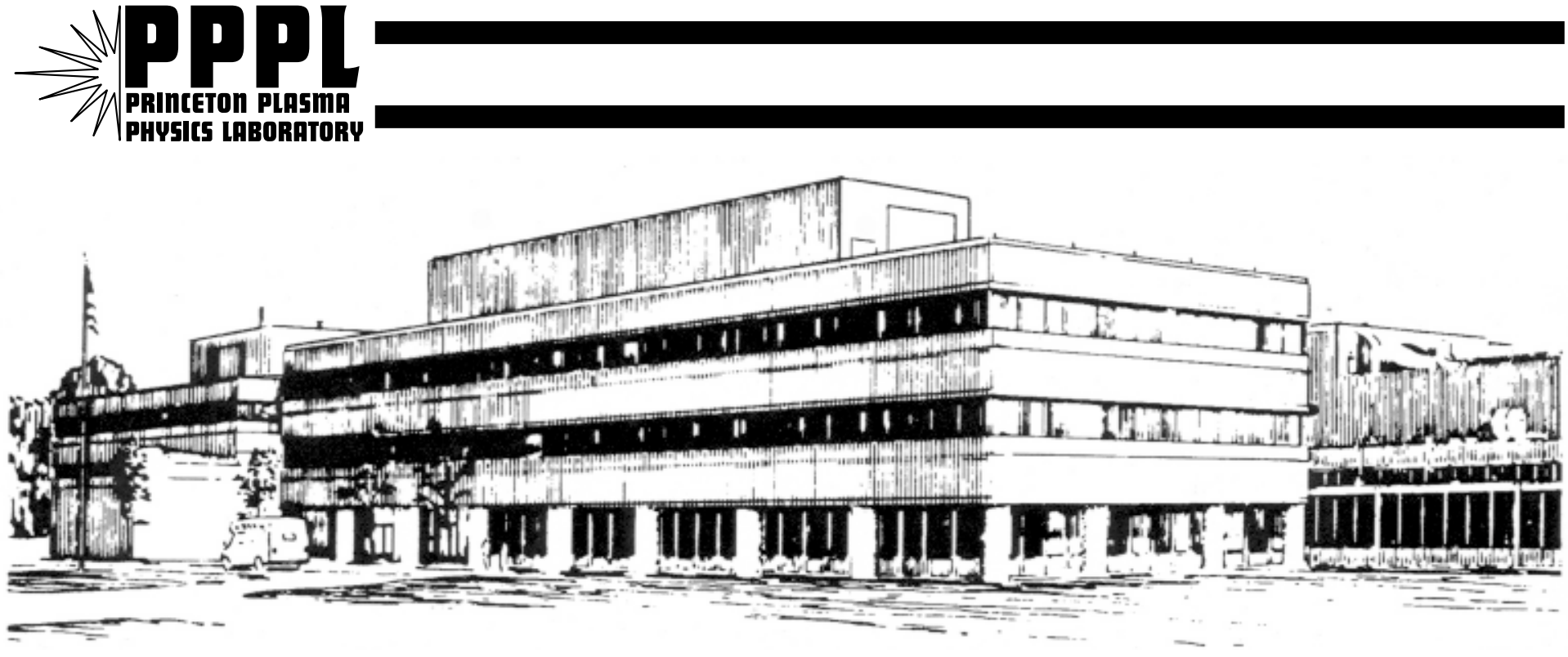

PRINCETON PLASMA PHYSICS LABORATORY PRINCETON UNIVERSITY, PRINCETON, NEW JERSEY 


\section{PPPL Reports Disclaimer}

This report was prepared as an account of work sponsored by an agency of the United States Government. Neither the United States Government nor any agency thereof, nor any of their employees, makes any warranty, express or implied, or assumes any legal liability or responsibility for the accuracy, completeness, or usefulness of any information, apparatus, product, or process disclosed, or represents that its use would not infringe privately owned rights. Reference herein to any specific commercial product, process, or service by trade name, trademark, manufacturer, or otherwise, does not necessarily constitute or imply its endorsement, recommendation, or favoring by the United States Government or any agency thereof. The views and opinions of authors expressed herein do not necessarily state or reflect those of the United States Government or any agency thereof.

\section{Availability}

This report is posted on the U.S. Department of Energy's Princeton Plasma Physics Laboratory Publications and Reports web site in Calendar Year 2001. The home page for PPPL Reports and Publications is: http://www.pppl.gov/pub_report/

DOE and DOE Contractors can obtain copies of this report from:

U.S. Department of Energy

Office of Scientific and Technical Information

DOE Technical Information Services (DTIS)

P.O. Box 62

Oak Ridge, TN 37831

Telephone: (865) 576-8401

Fax: (865) 576-5728

Email: reports@adonis.osti.gov

This report is available to the general public from:

National Technical Information Service

U.S. Department of Commerce

5285 Port Royal Road

Springfield, VA 22161

Telephone: 1-800-553-6847 or

(703) 605-6000

Fax: (703) 321-8547

Internet: http://www.ntis.gov/ordering.htm 


\section{SCREENING OF HYDROCARBON SOURCES IN JET}

J.D. Strachan ${ }^{1}$, W. Fundamenski ${ }^{2}$, M. Charlet ${ }^{2}$, K. Erents ${ }^{2}$, J. Gafert ${ }^{3}$, C. Giroud ${ }^{4}$, M von Hellermann ${ }^{5}$, G. Matthews ${ }^{2}$, G. McCracken ${ }^{2}$, V. Philipps ${ }^{6}$, J. Spence ${ }^{2}$, M.F.

Stamp $^{2}$, K-D. Zastrow ${ }^{2}$, and EFDA-JET Work Programme Collaborators*

${ }^{1}$ PPPL, PRINCETON UNIV, USA

${ }^{2}$ UKAEA, CULHAM, UK

${ }^{3}$ IPP, GARCHING, GERMANY

${ }^{4}$ CEA, CADARACHE, FRANCE

${ }^{5}$ FOM, NETHERLANDS

${ }^{6}$ KFA, JUELICH, GERMANY

*see appendix of J. PAMELA, PROC. IAEA CONF. (SORRENTO, 2000)

Introduction: Carbon is the principal impurity in JET. Methane screening experiments [1] quantify the ability of the SOL/divertor system to ionise carbon and transport it to the divertor, preventing core plasma contamination. Previous JET publications studied ELMaveraged H-Mode screening [2], and separately, evaluated the methodology of L-Mode screening measurements [3]. This paper extends the L-Mode measurements to include relevant plasma parameter scans, and DIVIMP modelling of the L-Mode screening.

Experiment: The carbon screening was measured by injecting deuterated methane $\left(\mathrm{CD}_{4}\right)$ for $3 \mathrm{~s}$ (about 6 energy confinement times) into JET plasmas from several main chamber and divertor locations (see Fig. 1 of [3]). The carbon screening, $S_{c}$ is defined as:

$$
\mathrm{S}_{\mathrm{c}}=\Delta \mathrm{N}_{\mathrm{c}} /\left(\Gamma_{\mathrm{c}} \tau_{\mathrm{p}}^{*}\right) \text {. }
$$

The core carbon content change, $\Delta \mathrm{N}_{\mathrm{c}}$ (due to the methane puffing) was measured by visible Bremsstrahlung (VB) or charge exchange $(\mathrm{CX}) . \tau_{\mathrm{p}}{ }^{*}$ was determined from the evolution of the core carbon content to be about the energy confinement time, $\tau_{\mathrm{E}}$. The screening so defined is the fraction of injected carbon that reaches the last closed flux surface (LCFS) [1]. JET L-Mode plasmas had $S_{c}$ values in the range of .05 to .2 for methane puffed from the outer, horizontal mid-plane (Fig.1).

The screening is determined by SOL phenomena and the JET SOL characteristic lengths depend upon density, applied power, and connection length [4]. L-Mode screening was measured scanning those parameters as well as the methane injection rate, and plasma current. Empirically, an L-Mode scaling, $\mathrm{S}_{\mathrm{c}}{ }^{*}$, for carbon injected as methane at the horizontal mid-plane, with the carbon content measured by VB, was obtained by regression:

$$
\mathrm{S}_{\mathrm{c}} *=0.1 /\left(\mathrm{n}_{\mathrm{e}}(0) \tau_{\mathrm{E}}\right)
$$

In equation (2), the central density, $\mathrm{n}_{\mathrm{e}}(0)$, has units of $10^{19} / \mathrm{m}^{3}$ and the gross energy confinement time, $\tau_{\mathrm{E}}$ has units of sec. The regression coefficients have been rounded to unity which accounts for the slightly poorer fit of the data in the current scan than in the density scan (Fig. 1). Equation (2) describes the JET L-Mode data within the $20 \%$ measurement uncertainty. 


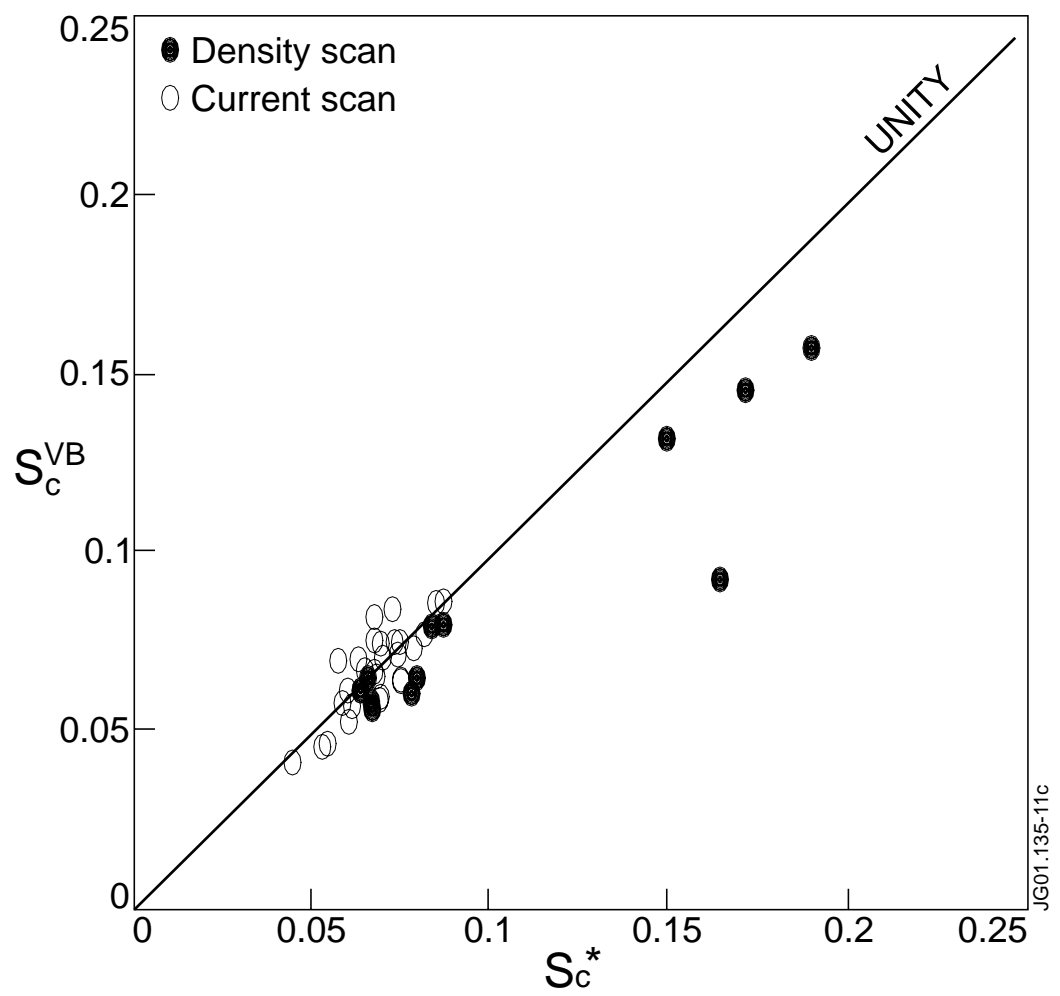

Fig. 1. L-Mode screening measured by visible Bremsstrahlung for density and current scans as a function of the JET empirical scaling, Equation (2).

Modelling: DIVIMP [5] was used to model the experiment, calculating that carbon injected at the mid-plane injected was ionised about 1 to $3 \mathrm{~cm}$ from the Last-Closed-FluxSurface (LCFS). DIVIMP also calculated that the thermal forces and the Coulomb coupling to the deuterium SOL flow dominated the parallel motion of the carbon ions. The carbon diffusion perpendicular to the field lines, has an unknown coefficient that might be related to the SOL ion thermal conductivity. Onion Skin Modelling [6] determined that the ion thermal conductivity was 0.1 to $0.15 \mathrm{~m}^{2} / \mathrm{sec}$ for these L-Mode plasmas. The DIVIMP code fits the measured $\mathrm{S}_{\mathrm{c}}{ }^{\mathrm{VB}}$ or $\mathrm{S}_{\mathrm{c}}{ }^{*}$ (Equation (2)) if the carbon diffusion coefficient is slightly smaller than the ion thermal conductivity and increases with density. The DIVIMP modelling gives a clear physical origin for the density dependence of the screening. At higher density, the carbon is ionised further away from the LCFS, and is more likely to transport to the divertor where it is deposited. We have yet to explore the meaning of $S_{c}{ }^{*}$ 's dependence upon confinement time and independence from connection length.

Using CX data (for $\Delta \mathrm{N}_{\mathrm{c}}$ in Equation (1)) yielded screening values $0.35 \%$ lower than using VB data (Fig. 2). That agreement is considerably better than reported in [3] due to re-calibration of the $\mathrm{CX}$ system alignment. The Carbon particle diffusion coefficient required by DIVIMP to fit the CX experimental screening is also correspondingly reduced.

The general features of the $\mathrm{CD}_{4}$ fuelling location scan (fig. 2) were modelled by DIVIMP with the worst screening observed at the mid-plane and the best screening observed in the divertor. The screening at the machine top was twice as good as that 


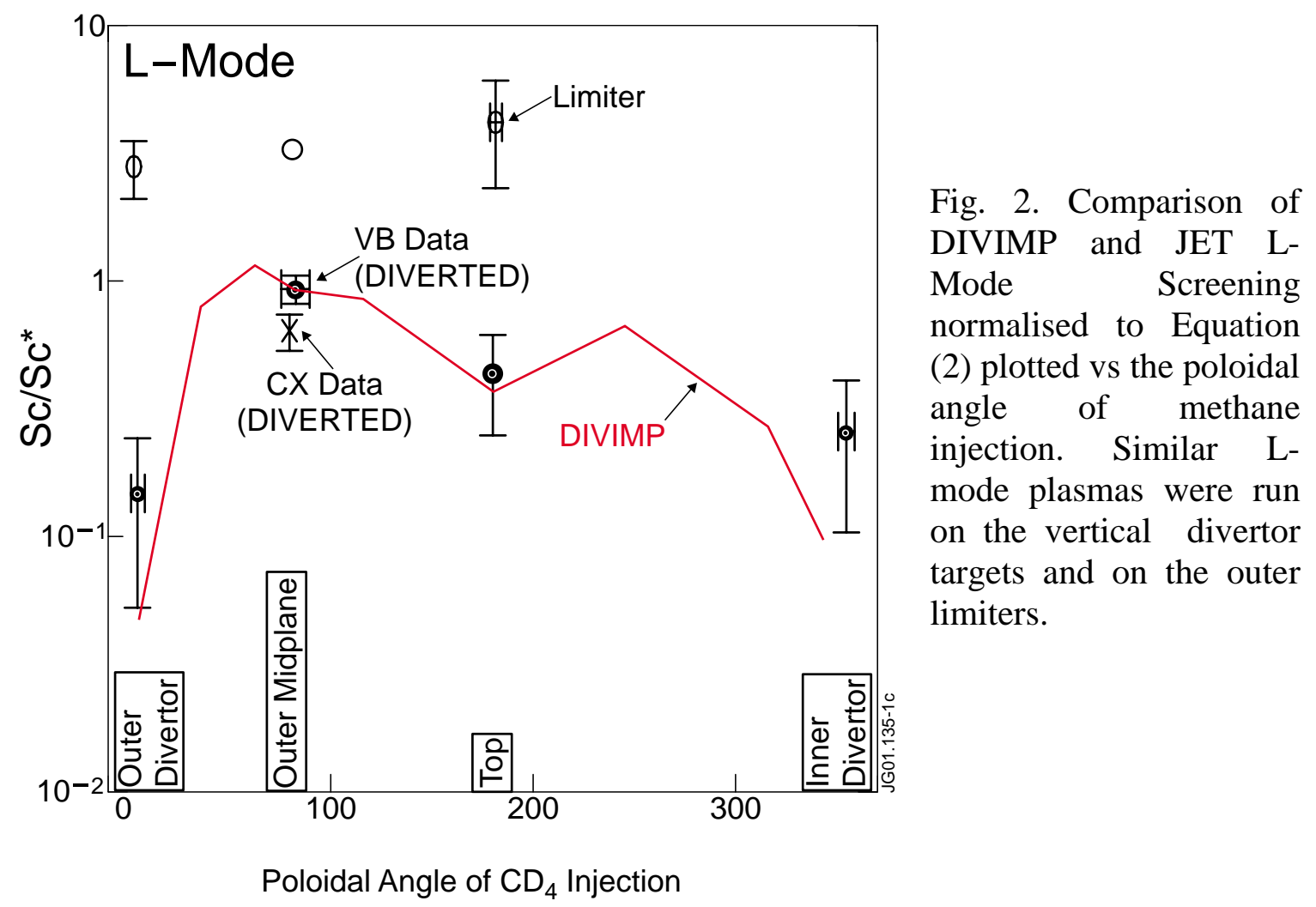

observed at the horizontal mid-plane, and indicated the importance of the SOL flow (usually measured to be a Mach number of 0.5 at the vessel top but, presently not understood, and therefore not calculated in DIVIMP). Flows could be imposed upon the DIVIMP SOL, and SOL flow patterns with a stagnation point near the vessel top had worse screening at the top, relative to the mid-plane. Also shown in Figure 2 is the screening of similar JET L-mode, limited plasmas. These plasmas had 3 to 5 times worse screening than the diverted plasmas, indicating the effectiveness of the divertor/SOL at screening hydrocarbon sources located in the main chamber or divertor. The screening of the limited plasmas was independent of methane fuelling location. The DIVIMP calculation of the divertor screening indicates better screening was calculated than was observed. Possibly, the experimental values were influenced by methane gas leakage out of the divertor.

Discussion: Screening was also measured for different plasma configurations (Fig. 3). Operation with the strike points located in the corner (the pump port in the divertor) did not change the screening though increasing the deuterium pumping.

A "high clearance" plasma was designed to increase the main chamber clearance (closest approach) of the LCFS from typically $5 \mathrm{~cm}$ to $15 \mathrm{~cm}$. However, the screening for 


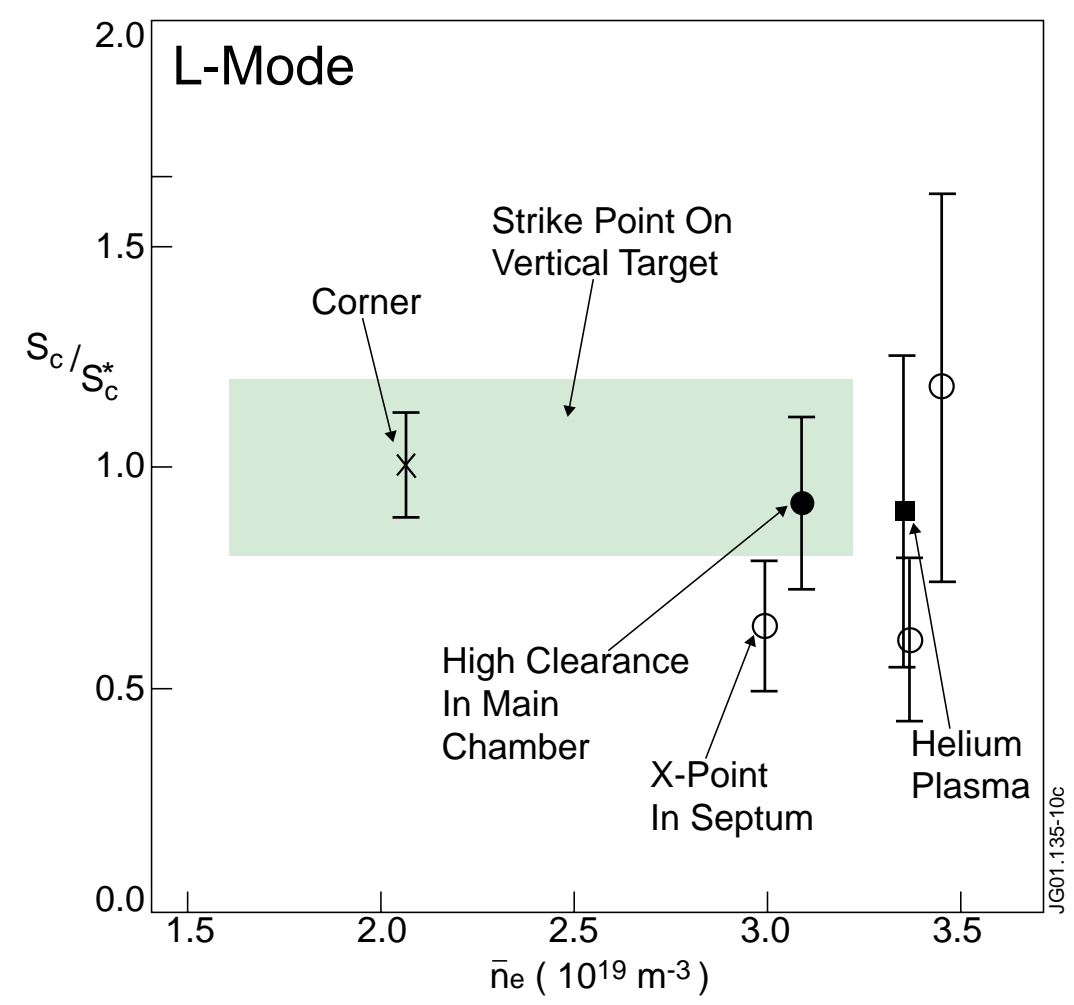

Fig. 3. The carbon screening normalised to Equation (2) for $2.5 \mathrm{MA}$ L-Mode plasmas plotted vs density. The shaded region represents the deuterium plasmas from Fig. 1 with strike points on the vertical targets in the divertor and X-Point about $10 \mathrm{~cm}$ above the Septum surface. Midplane methane injection was used for all discharges.

methane injected at the horizontal mid-plane, did not change. Apparently, location of material surfaces (such as RF antennae or poloidal limiters) inside the main chamber and within $5 \mathrm{~cm}$ of the LCFS do not affect the methane screening or divertor performance.

Operation with the X-Point embedded into the top of the Septum, did not significantly change the methane screening. Such operation makes the divertor similar to a pumped limiter. The fact that the screening was unchanged (or slightly improved) may indicate that it is possible to separate the carbon impurity pumping from the heat flow.

The horizontal mid-plane, $\mathrm{CD}_{4}$ screening of helium L-Mode plasmas (heated by Helium neutral beams) was also consistent with equation (2). Apparently, the helium SOL screened carbon similarly to a deuterium SOL even though the higher Coulomb collisional coupling to helium should accelerate Carbon ions faster towards the divertor.

Summary: Methane screening experiments in JET L-Mode plasmas indicate the divertor is effective at preventing impurities from reaching the plasma core. Empirically, the screening improved at higher density and higher energy confinement.

\section{References:}

[1] G. M. McCracken, et al, Nucl. Fus. 33, 1409 (1993)

[2] M. F. Stamp, et al, J Nucl. Mat. 266-269, 685 (1999)

[3] J. D. Strachan, et al, J. Nucl. Mat. 290-293, 972 (2001)

[4] S. K. Erents, et al, Nuclear Fusion 40, 295 (2000)

[5] P.C. Stangeby, et al, J. Nucl. Mat. 241-243, 358 (1997)

[6] P. C. Stangeby and J. D. Elder, J. Nucl. Mat. 196-198, 258 (1992) 


\section{External Distribution}

Plasma Research Laboratory, Australian National University, Australia

Professor I.R. J ones, Flinders University, Australia

Professor J oão Canalle, Instituto de Fisica DEQ/IF - UERJ , Brazil

Mr. Gerson O. Ludwig, Instituto Nacional de Pesquisas, Brazil

Dr. P.H. Sakanaka, Instituto Fisica, Brazil

The Librarian, Culham Laboratory, England

Library, R61, Rutherford Appleton Laboratory, England

Mrs. S.A. Hutchinson, JET Library, England

Professor M.N. Bussac, Ecole Polytechnique, France

Librarian, Max-Planck-Institut für Plasmaphysik, Germany

J olan Moldvai, Reports Library, MTA KFKI-ATKI, Hungary

Dr. P. Kaw, Institute for Plasma Research, India

Ms. P.J . Pathak, Librarian, Insitute for Plasma Research, India

Ms. Clelia De Palo, Associazione EURATOM-ENEA, I taly

Dr. G. Grosso, Instituto di Fisica del Plasma, Italy

Librarian, Naka Fusion Research Establishment, J AERI, J apan

Library, Plasma Physics Laboratory, Kyoto University, J apan

Research Information Center, National Institute for Fusion Science, J apan

Dr. O. Mitarai, Kyushu Tokai University, J apan

Library, Academia Sinica, Institute of Plasma Physics, People's Republic of China

Shih-Tung Tsai, Institute of Physics, Chinese Academy of Sciences, People's Republic of China

Dr. S. Mirnov, TRINITI, Troitsk, Russian Federation, Russia

Dr. V.S. Strelkov, Kurchatov Institute, Russian Federation, Russia

Professor Peter Lukac, Katedra Fyziky Plazmy MFF UK, Mlynska dolina F-2, Komenskeho Univerzita, SK-842 15 Bratislava, Slovakia

Dr. G.S. Lee, Korea Basic Science Institute, South Korea

Mr. Dennis Bruggink, Fusion Library, University of Wisconsin, USA

Institute for Plasma Research, University of Maryland, USA

Librarian, Fusion Energy Division, Oak Ridge National Laboratory, USA

Librarian, Institute of Fusion Studies, University of Texas, USA

Librarian, Magnetic Fusion Program, Lawrence Livermore National Laboratory, USA

Library, General Atomics, USA

Plasma Physics Group, Fusion Energy Research Program, University of California at San Diego, USA

Plasma Physics Library, Columbia University, USA

Alkesh Punjabi, Center for Fusion Research and Training, Hampton University, USA

Dr. W.M. Stacey, Fusion Research Center, Georgia Institute of Technology, USA

Dr. J ohn Willis, U.S. Department of Energy, Office of Fusion Energy Sciences, USA

Mr. Paul H. Wright, Indianapolis, Indiana, USA 
The Princeton Plasma Physics Laboratory is operated by Princeton University under contract with the U.S. Department of Energy.

\author{
Information Services \\ Princeton Plasma Physics Laboratory \\ P.O. Box 451 \\ Princeton, NJ 08543
}

Phone: 609-243-2750

Fax: 609-243-2751

e-mail: pppl_info@pppl.gov

Internet Address: http://www.pppl.gov 